Two significant, though not exclusive, lines of development are worthy of comment. First, degree courses in biology per se are being established in contrast to tho traditional study of botany and zoology as separale diseiplines. Such an approach placos omphasis on the integration of plant and animal studies, on unitary eoncepts in biology and on a fuller approsiation of plantanimal interactions. Secondly, microbiology is coming to be recognized as a dogroe subject in its own right, no longor to be equated with medical bactoriology or othor narrow specialist treatmonts. These two approuches have much in oommon, among the most important being their attempts to integrate und rationalize biology and to requiro its firm basis in the physical seiences.

Although the output of microbiology graduates from British universities and colleges is smenll, the present demands from industry and research laboratories aro considorable and ever expanding. On his appointment to the newly created chair of microbiology in University College, Cardiff, Prof. D. F. Hughes has directed timely attention to this widening scope and importance of microbiology (Microbes in Action. An Jnnugural Lecture delivorod at University Colloge, Cardiff, April 30, 1965 By Prof. D. E. Hughes. Pp. 21. Cardiff: University of Wales Press, 1965. 3s.6a.). Apart from tho moro academic aims and achievements of contemporary microbiology, reference is made to the extension of industrial processes, based on the activities of micro-organisms, and to the technological exigencies imposed by such operations. Prof. Hughes's inaugurnd addross presents a broad survey of miorobiology and gives heed to its further advance, exploitation and some possible consequences of its noglect. It is to be hoped that the training of graduates in this field will keep pace with the requirements of industry and elsewhere and that disparity in present supply and demand will be redrossed. The time is opportune for" A careful assessment of the typos of biologist Britain needs and will continue to need in the approaching decade; the recent misjudgment of the number of medically qualified graduates required is a cogent, argument for such an onquiry.

\section{Royal Society/Royal Geographical Society Expedition to Mid-West Brazil}

The Royal Society and the Royal Geographical Society are considering jointly sponsoring scientific investigation in the little-known juterior of Mato Grosso in mid-wost Brazil. A reconnaissance party of three is now on its way for is two-month visit to diseuss with Brazilimin scientists and officials plans for a larger oxpedition from Britain, possibly next yoar.

The leader of the reconnaissance party is $\mathrm{Mr}$. A. F. MacKenzie, a tropical plant, ecologist, and he will be accompanied by Mr. I. R. Bishop, a zoologist from the University of Leicester, and Mr. D. R. Hunt, a botanis from the Royal Botanic Gardens, Kew. Mr. Maekenzie sailed for Rio de Janeiro in mid-April, with the reconnaissance party's supplies, and will be followed shortly by Messrs. Bishop and Hunt.

\section{Lasers for "Teaching}

The laser is now an accepted new light source for use both in toaching laboratories and in scientific and technological research. Though specifically related to the domountable continuous gas laser produced by Scientifica and Cook Electronics, Ltd., the manual entitled The Gas Laser and its Experimental Applications, by R. J. Horton and P. D. Cook, is a valuable and easily understood guide to various experiments which can be used for teaching and demonstration purposeg using a helium-neon gas laser (Pp. 31. London: Seintifica and Cook Electronies, Ltd., 1965. 12s. 6d.). Detailed instructions are given for align= ment and operation of the laser, in addition to the precautions necessary while handling tho source. A clear introductory statement deseribes the theory of the laser, and the various cavity arrangements and the dependence of astion of the lascr on them. The experiments choson as examples consist of the demonstration of lens aberrations, Fraunhofer diffraction and interference patterns, Fourier transforms, the Michelson interferometer, and the Abbé theory of image formation.

\section{Root Rot of Teak}

DR. B. K. BAKshI, of the Forest Research Institute, Dehra Dun, India, has written to the Editor reporting an outbreak of root rot diseases of teak (Tectona grandis Linn. f.). The outbreak occurred in a plantation at the demonstration forest attached to the Institute (the plantation was established in 1928 and coppiced during 1945): "Two pathogens were encountered, namely, Polyporus zonalis Berk., and a spocies of Penioploro. The decay in the roots has resulted in wind throw of trees. So far as I can enscertain, Peniophora has not previously been recorded in teak. It colonizos old coppiced stumps and spreads freely through the soil by means of yellow rhizomorphs which infect healthy roots, in which a yellow spongy or yellow laminated decay develops. Sporophores are common. The fungus has not been encountered before".

\section{Geological Society of London}

At the annual general meeting of the Geological society of London on April 27 the officers and Council for the ensuing year were elected as follows: President, Prof. K. C. Dunham, University of Durham; Secretaries, W. B. Harland, University of Cambridge; Prof. J. Sutton, Imperial College of Science and Technology; Foreign Secretary, Prof. O. M. B. Bulman, University of Cambridge; Treasurer, Dr. W. Bullerwell, Geological Survey and Museum.

\section{U.S. National Academy of Sciences}

Dr. H. Brown, professor of geochemistry at the California Institute of Technology, has been elected to a second four-year term as foreign secretary of the U.S. National Academy of Sciences. The following were also clected members of the Couneil of the Academy for a three-year period: Prof. H., E. CARTER, heid of the Department of Chemistry, University of Illinois; Prof. J. L. Grennstein, head of the Department of Astrophysics and shairman of Faculty, Mount Wilson and Palomar Observatories, California Institute of Technology; Prof. W. (O. 'FrNN, professor of physiology, School of Medicine and Dentistry, Unjversity of Rochester; Prof. EsAu, emeritus professor of botany, University of California.

\section{Zoological Society of London}

THe Zoological Socicty of London has made the following awards: Silver Medal, Mr. D. Attenborough of Richmond, Surrey; Scientific Medal, Dr. F. H. Ashton, the Medical School, University of Birmingham; Mr. B. B. Boycott, University College, London; Dr. R. M. Laws, Nuffield Unit of Tropical Animal Ecology, Queen Elizabeth Na. tional Park, Uganda; Stamford Raffles Award, Dr. E. G. Neal, 'Taunton School, Somerset; Thomas Henry Huxley Award, Dr. J. S. Gray, University of Leeds; Prince Philip Prize, M. E. Greenhalgh, formerly of Kirkham Grammar School.

\section{The Australian Academy of Science: New Officers}

Ar the annual election of officers of the Australian Academy of Science on April 28, the following were olocted: President, Sir Macfarlane Burnet; Secretary (physical soiences), Dr. A. L. C. Rees; Secretary (biological sciences), Prof. R. J. Walsh; Treasurer, Sir Hugh Finnor. 